\title{
ON TACTICAL CROP MANAGEMENT USING SEASONAL CLIMATE FORECASTS AND SIMULATION MODELLING - A CASE STUDY FOR WHEAT
}

\author{
H. MEINKE'; R.C. STONE' \\ 'Agricultural Production Systems Research Unit (APSRU), DPICSIRO and DNR, P.O. Box 102, Toowoomba, Q. 4350, \\ Australia.
}

\begin{abstract}
The EI Nino/Southem Oxclliation phenomenon strongly infinences rainfall distribution around the world. Uaing phases of the Sonthern Oxclltation Index (SOI) allow a probobilistic forecant of future rainfall that can be useful to managers of agricultural syutems. Using wheat as an example, we show in this study how the SOI phase gystem, when comblned with a cropphy systems simulation capability, can be used operationally to improve tactical crop management and hence increase farm profits and/or decrease production risks. We show the validity of the approach for two contrasting locations, namely Dalby in Northerm Australian and Piracicaba in Braval. At Dalby, highest median yields were achleved following a rapidly rising SOI phase in AprilMay and lowest median yields following a consistently negative phase. Conversely, highest median yields at Piracicaba followed a near zero April/May phase and lowest median yields when the phase was consistentiy positive. We show how tactical management options can range from crop or cultivar choice to nitrogen management and maricting of the future whent crop.
\end{abstract}

Key Words: climatic variablity, crop and systems modelling, crop production forecasts

\section{PROCEDIMENTO DE MANEJO CULTURAL UTHIZANDO PREVISÃO CLIMÁTICA E MODELOS DE SIMULAÇÃO - UM ESTUDO DE CASO PARA A CULTURA DE TRIGO}

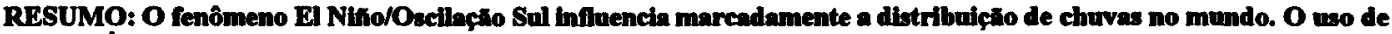
fases de fndice de Oscilnçio Sul (IOS) permite ume previsio probabllistica da precipitaçio pluvil futura, que pode ser ftil para o manejo de sistemas agricolas. Usando-se trigo como exemplo, fol demonstrado nesse estudo, como o sistema de fases IOS, quando combinado com modelos de simulactio de sistemas de cultivo, pode ser usado para melhorar o manejo tatico de culturas e asolm aumentar os lucros e/ou diminuir os riscos da produchio agricola. A validade desse método 6 mostrada para dois locais diferentes, Dalby, na Austrilia e Piracicaba, no Brasil. Em Dalby, os maiores rendimentos médios foram obtidos ap6s um aumento rápido na fase IOS em abril/malo e os menores rendimentos médios após uma fase negativa consiatente. Em Piracicaba, os malores rendimentos médios foram alcancados após uma fase próxima a zero em abrilmaio e os menores rendimentos medios, quando a fase foi consistentemente positiva. E mostrado como as opföes de manejo títico podem variar da escolha de cultivares ao manejo de nitrogênio e de mereado da cultura de trigo.

Descritores: variablidade climitica, modelagem de cultura e sistemas, previsoes de produçio agricola

\section{BACKGROUND}

Simulation models of crops or even whole cropping systems are used for many purposes and in many different ways. Applications range, among many others, from giving guidance to policy makers (Netherlands Scientific Council for Government Policy, 1992), land use evaluation (Meinke \& Hammer, 1995a), assisting management decisions at the farm level (Woodruff, 1992), plant breeding and adaptation (Cooper \& Hammer, 1996), risk analysis (Meinke \& Hammer, 1995b; Meinke et al., 1996b) to teaching of crop physiological principles (Lovenstein et al., 1995). In addition to such, often single crop applications, simulation techniques are increasingly used for cropping systems analysis (Littleboy et al., 1992; Fischer, 1995). The cropping systems model APSIM (McCown et al., 1996) was specifically developed for these purposes and an overview of the diversity of applications is given by Meinke et al. (1996a). In this paper we demonstrate, how the combination of recent advances in long-range forecasting and simulation modelling can impact directly on the tactical decision making process at the farm level. 


\section{INTRODUCTION}

High rainfall variability is the major source of dryland wheat yield fluctuations in north-eastern Australia (Hammer et al. 1987) and elsewhere in the semi-arid tropics and subtropics. The year-to-year yield fluctuations leads to similar fluctuations of the world market price for wheat and hence results in high income uncertainty for primary producers if they are not protected by government intervention such as in the US or in the European Union. To remain economically viable, Australian farmers have to devise management options that can produce long-term, sustainable profits in such a variable environment. This requires some knowledge of likely climatic conditions for the season ahead.

Significant, physically based lagrelationships exist between an index of the ocean/atmosphere El Ninfo/Southern Oscillation phenomenon (ENSO) and future rainfall amount and temporal distribution in eastern Australia and many other areas across the globe (Stone et al., 1996a). An El Niño event, which generally corresponds to negative Southem Oscillation Index values (SOI), usually lasts for about 12 months, beginning its cycle in the austral autumn period of one year and terminating in the autumn period of the following year. During the termination of an El Niño event the SOI may rise sharply. Stone et al. (1996a) have shown how phases of the SOI are related to rainfall variability and are useful for rainfall forecasting for a range of locations in Australia and around the world. For Australia, they have shown that a rapid rise in SOI over a two months period is related to a high probability of above long-term average rainfall at certain times of the year. Conversely, a consistently negative or rapidly falling SOI pattern is related to a high probability of below average rainfall for many regions in Australia at certain times of the year. As the SOI pattern tends to be 'phase-locked' into the annual cycle (from autumn to autumn), the SOI phase analysis also provides skill in assessing future rainfall probabilities during the subsequent growing season.

A skilful seasonal forecast provides an opportunity for farm managers to better tailor crop management decisions to the season (Hammer et al., 1996b). Timing and frequency of future rainfall events strongly influences dryland crop growth and yield and the usefulness of rainfall events in terms of their contribution to crop production is difficult to assess. However, physiologically based simulation models can be used as 'filters' to gauge the value of rainfall over a growing season (Meinke \& Hammer, 1997). Using phases of the SOI in conjunction with dynamic simulation models allows better quantification of climatic risk. For instance, for peanuts grown in Northern Australia, Meinke et al. (1996b) showed that higher yields are generally associated with a consistently positive SOI phase in August/September due to higher and more reliable summer rain coupled with a lower frequency of rain at harvest.

For wheat, Hammer et al. (1996b) showed how tactical nitrogen management and cultivar choice based on SOI phases can increase profitability in Northern Australia. Khandekar (1996) showed that El Niño events are usually associated with low grain yields over South Asia and Australia and high grain yield throughout the North American prairies.

This paper demonstrates how a simulation capability combined with climate forecasting can aid producers in the decision making process. It also shows, how the methodology can be applied to forward estimate wheat production either prior to sowing or shortly after sowing for a location in Australia and a location in Brazil. While many of the tactical management options appear to be generic in nature, their usefulness in Brazil and other parts of the world remains to be proven.

\section{METHODS}

Wheat is the major winter crop grown in North-eastern Australia. The area is dominated by summer rainfall and hence stored soil moisture is necessary in low rainfall years to avoid crop failure and in high rainfall years to achieve the environmental yield potential.

Climatic Conditions: An El Nifo event usually results in substantially below average rain in many parts of Australia, India and South Africa, but higher than average rainfall for large areas of South America and parts of the US (Stone et al., 1996a). As the SOI pattern tends to be 'phaselocked' into the annual cycle (from autumn to autumn), the SOI phase analysis provides skill in assessing future rainfall probabilities during the subsequent growing season. 
By April 1997, sea surface temperature anomalies in the Eastern Pacific indicated a high likelihood of an El Nifio developing. More importantly in terms of the climate forecast system used here, the monthly average SOI values dropped drastically in early 1997 from an average value of +12 in February to -14 by the end of April. If the trend continues, an El Niño may have developed by mid 1997 and would be likely to persist until at least early 1998.

SOI Phases: The forecast method employed for this study is based on knowledge of the SOI phase for April/May. Briefly, the method uses Principal Components Analysis and Cluster Analysis to categorise SOI values into five phases or "types" (Stone et al., 1996a). The SOI phases comprise: consistently negative (cons -ve), consistently positive (cons +ve), rapidly falling (rap fall), rapidly rising (rap rise) and near zero (near ' 0 ').

To quantify the impact of current skill of long-term rainfall forecasts, each year of simulated yields was categorised according to the corresponding April/May SOI phase. For each SOI phase cumulative distribution functions were calculated.

Simulations: To evaluate likely wheat yields for the forthcoming season we used the cropping systems model APSIM configured for wheat (cultivar 'Hartog') in conjunction with long-term, daily weather records (McCown et al., 1996; Meinke et al., 1997). The model requires daily meteorological data (i.e. minimum and maximum temperature, solar radiation and rainfall) as inputs. Leaf area index is determined as a function of mean daily temperature and daily biomass accumulation is calculated as a linear function of the intercepted solar radiation or amount of water transpired, depending on whether solar radiation or soil moisture is limiting biomass production. Both, leaf area and biomass production, are sensitive to the amount of soil water and nitrogen available for transpiration. A cascading soil water balance takes account of rainfall, evaporation and transpiration throughout the year. Yield is calculated as a function of biomass production and growing conditions during yield formation. Developmental phases of the crop are related to thermal time. The model does not account for factors such as waterlogging, pests or diseases.
Two locations, namely Dalby in Queensland, Australia $\left(27^{\circ} \mathrm{S}, 151^{\circ} \mathrm{E}\right)$ and Piracicaba in Brazil $\left(23^{\circ} \mathrm{S}, 47^{\circ} \mathrm{W}\right)$ were considered. Long-term daily meteorological data were available from 1886 to 1993 and from 1917 to 1996 for Dalby and Piracicaba, respectively. The simulations reflect typical soil profiles and sowing dates at both locations. Nitrogen limitation can mask the effect of favourable rainfall seasons and hence it was assumed that nitrogen did not limit production. At Dalby, a soil profile holding up to $254 \mathrm{~mm}$ of plant available water was used and wheat was sown every year on 20 May. At Piracicaba soils are much shallower and hold less water. Also, wheat is generally sown earlier than at Dalby. Hence, we used a profile with $87 \mathrm{~mm}$ of plant available water holding capacity and yearly sowing on 20 April. To allow for different fallow situations, three different starting soil moisture conditions were considered, namely profiles that were either 20 , 50 or $80 \%$ full at sowing.

\section{RESULTS}

SOI phases: SOI phases have been reconstructed for every month dating back to the beginning of atmospheric pressure records in 1878. For the April/May period, phases cons -ve, cons +ve, rap fall, rap rise and near ' 0 ' have occurred 17, 28, 15,29 and 31 times, respectively (Fig. 1). It is noteworthy that phase cons -ve has accurred four times already since 1991 and is likely to occur again this season in 1997. At this stage we are uncertain if this is purely a statistical aberration or associated with a more fundamental shift in weather patterns. In any case, these two phases normally signify El Niño conditions that have been responsible for on of the most severe and prolonged drought Eastern Australia has experienced this century (Keating et al., 1996).

Stone et al. (1996a) have shown how the same SOI phase can indicate either higher or lower than average rainfall probabilities for the following 3-months period, depending on location and time of the year. For instance, a consistently negative SOI phase for April/May indicates a high probability of below median rain for June to August for Eastern Australia, parts of South-east Asia, India, South Africa and the Sahel while parts of South America, USA, southern Canada and Western Europe can expect a high probability of above median precipitation during that time. 


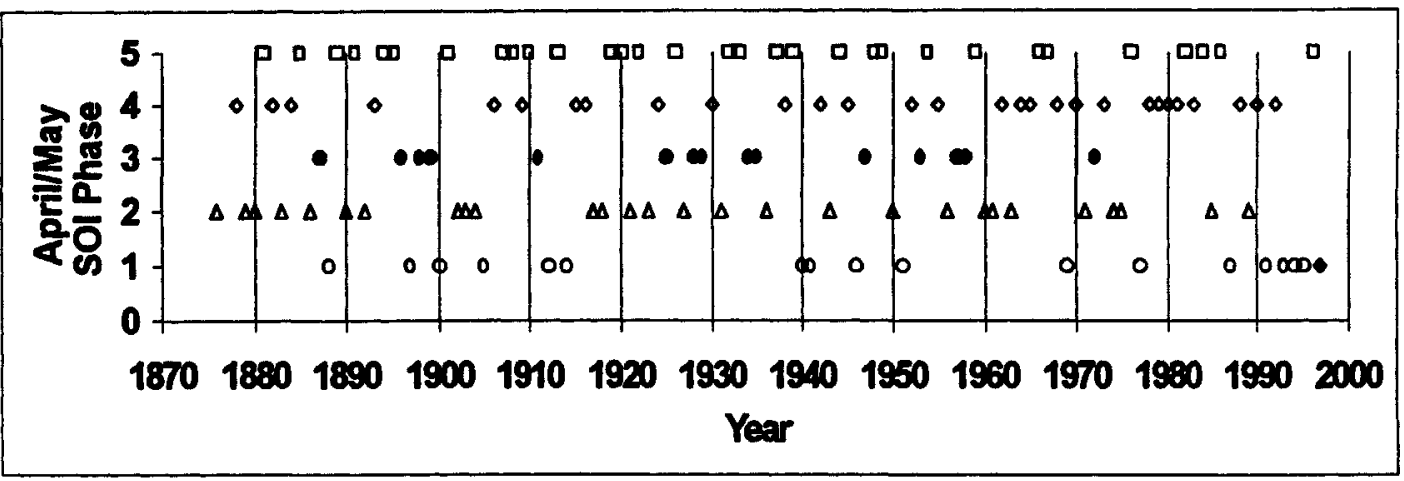

Figure 1 - April/May SOI phases since the beginning of atmospheric pressure records. Values 1 to 5 correspond to SOI phases consistently negative, consistently positive, rapidly falling, rapidly rising and near zero, respectively. Note that the April/May phase for 1997 is an estimate at this stage and indicated by a solid symbol.

TABLE 1 - Simulated median wheat yields at Dalby and Piracicaba in response to starting soil moisture (SSM) conditions. The soils can hold a maximum of 254 and $87 \mathrm{~mm}$ of plant available water at Dalby and Piracicaba, respectively. The three SSM conditions correspond to soil profiles that are either 20,50 or $80 \%$ full at sowing. Shown are median yields for the entire record ('all years', 107 years at Dalby and 80 at Piracicaba) in $\mathrm{g} \mathrm{m}^{-2}$ and the median values of the five SOI categories, expressed as percent of the 'all years' case

\begin{tabular}{|c|c|c|c|c|c|c|}
\hline \multirow{2}{*}{$\begin{array}{c}\text { All Years } \\
\text { (yield, } \mathrm{g} \mathrm{m}^{-2} \text { ) }\end{array}$} & \multirow{2}{*}{$\begin{array}{l}\text { SSM } \\
(\mathrm{mm})\end{array}$} & cons -ve & cons tve & rap fall & rap rise & near ' 0 ' \\
\hline & & \multicolumn{4}{|c|}{- (yield, percent of 'all years') } & \\
\hline \multicolumn{7}{|l|}{ Dalby } \\
\hline 616 & $206(=80 \%)$ & 94 & 98 & 92 & 107 & 103 \\
\hline 380 & $129(=50 \%)$ & 69 & 100 & 88 & 117 & 108 \\
\hline 71 & $48(=20 \%)$ & 68 & 99 & 75 & 292 & 159 \\
\hline \multicolumn{7}{|l|}{ Piracicaba } \\
\hline 115 & $70(=80 \%)$ & 102 & 61 & 114 & 94 & 110 \\
\hline 84 & $44(=50 \%)$ & 116 & 64 & 73 & 78 & 131 \\
\hline 52 & $17(=20 \%)$ & 125 & 74 & 89 & 97 & 124 \\
\hline
\end{tabular}

Based on the historic record (17 of 107 years of record) combined with our current knowledge and understanding of the climate systems (sea surface temperature anomalies currently indicate the probable development of an El Niño, in 1996 we experienced a weak La Nina), a consistently negative SOI phase is the likely scenario for April/May 1997. However, a rapidly falling phase could also still occur, should pressure values in the Eastern Pacific remain low for the rest of May 1997.

Wheat yields: Starting soil moisture (SSM) conditions affected the expected yield range at both locations strongly, in line with expectations for summer rainfall dominated environments. The median yields of the 'all years case' at both locations and for similar starting conditions (i.e. 
SSM $20 \%$ at Dalby and $50 \%$ at Piracicaba, respectively) hardly differed, indicating the similarity of the environments (Table 1). The large differences between the locations for yields $>200 \mathrm{~g} \mathrm{~m}^{-2}$ is the result of the 3 times higher water holding capacity of the soil at Dalby (Figure 2). It reflects the fact that in about $30 \%$ of years sufficient rain falls during the cropping season to fill the profile at Dalby beyond the maximum storage capacity of the soil at Piracicaba.

At Dalby, median yields increase from $71 \mathrm{gm}^{-2}$ at $20 \%$ starting soil moisture to $380 \mathrm{gm}^{-2}$ at $50 \%$ and to $578 \mathrm{gm}^{-2}$ at $80 \%$ SSM, respectively. However, these effects differed strongly with SOI phases. In particular, three phases result in notably different yields: phases cons -ve and rap fall resulted in the lowest median yields and phase rap rise resulted in the highest median yield. Phase near ' 0 ' also increased median yield under low SSM (TABLE 1). Under low SSM median yields in phase cons ve only yielded about $25 \%$ of yields in years with a phase rapid rise. While this effect was still noticeable under higher SSM, its relative magnitude diminished as water stress is reduced due to the availability of sub-soil moisture. At $80 \%$ SSM, median yields for phase cons -ve represented $87 \%$ of those expected for rapid rise.

Likewise, median yields at Piracicaba more than doubled when SSM conditions were increased from $20 \%$ to $80 \%$. Positive and negative effects of SOI phases were amplified under low SSM conditions. Highest median yields can be expected following a near ' 0 ' phase. However, while a cons +ve phase at Dalby indicates approximately 'all years' conditions (i.e. no skill due to the SOI phase analysis at the median level), median yields at Piracicaba are reduced by between 39 and $26 \%$, depending on SSM. Conversely, following a cons -ve phase, median yields at Dalby are reduced by 6 to $32 \%$ while they are increased at Piracicaba by 2 to $25 \%$. Finally, should a cons -ve SOI phase be confirmed by the end of May 1997, median wheat yield expectations at a given SSM level would be below average at Dalby, but above average at Piracicaba for the 1997 season.

However, the analysis of median yield outcomes is insufficient if the true risks of production need to be considered. This requires an analysis of all likely outcomes within an SOI phase. Fig. 2 shows the probabilities of exceeding a certain yield level for the two locations and the two most similar SSM, namely $20 \%$ at Dalby and $50 \%$ at Piracicaba. While Fig. 2 indicates a greater segregation of yield distributions at Dalby based on SOI phases, this is largely associated with the greater water storage capacity of the soil at Dalby. For a true comparison of ENSO effects in these two environments a more thorough simulation study should investigate identical, hypothetical soil profiles for a range of summer and winter crops. However, Fig. 2 clearly demonstrates that the environmental potential yield at Dalby can never be achieved following either a phase con -ve or rap fall. Further, it shows the clear yield advantage that can be achieved at Piracicaba following either phase near ' 0 ' or con -ve.

\section{DISCUSSION}

Climate: Stone et al. (1996a) showed how median rainfall values following a certain SOI phase can differ strongly from the climatological median in many parts of the world. Our finding of 'better than average' wheat yields at Piracicaba following a cons -ve SOI phase is consistent with findings by Stone et al. (1996a), although this climate station was not included in their original analysis.

Implications for tactical crop management: Our results show that the same phases of the SOI when combined with a systems simulation capability can be used to estimate probable future wheat yields in Australia and in Brazil. It is likely that similar associations could be derived for most of the major dryland wheat producing regions in the world (Khandekar, 1996). In this study, we have only taken the effects of rainfall variability based on SOI phases into account. Stone et al. (1996b) have shown that a similar system can also be applied to estimate frequency, timing and severity of damaging frost around anthesis in Northern Australia. Similar type of analyses need to be conducted for other parts of the world. While these findings are scientifically interesting, the question that needs to be addressed is: How can this knowledge be applied to increase yield stability and ultimately farm profits? 

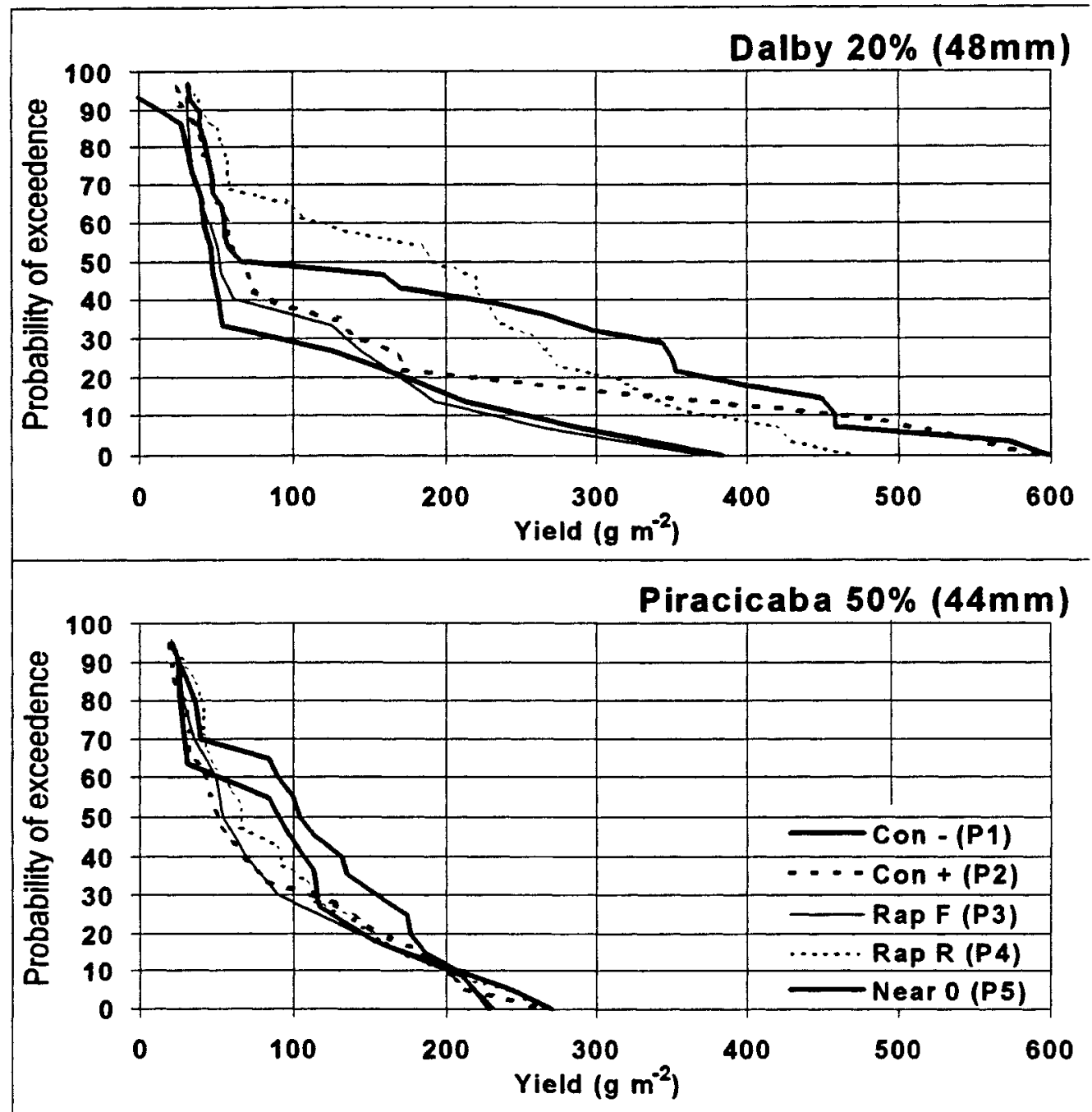

Figure 2 - Probability of exceeding a certain yield level following a certain April/May SOI phase at Dalby and Piracicaba. Shown are scenarios that are similar in their starting soil moisture (SSM) conditions. Soils at the two location differ strongly in their maximum plant available soil water holding capacity, explaining the much higher yields that can be achieved at Dalby in certain years

By late April / early May 1997 the combination of sea surface temperature anomalies and monthly SOI values indicated a high probability of an El Niño developing by mid 1997. The SOI phase system, which recognises this 'phase-locking' of ENSO into an annual cycle, indicated a high probability of below average rainfall for the coming austral winter/ spring period. At the same time, producers were getting ready to sow their winter crops. The sowing window lasts approximately from mid April to early July, whereby potential yields decline rapidly towards the end of this period. This yield penalty has to be balanced against a higher risk of frost damage occurring with earlier sowings (Woodruff, 1992). Hence, we conducted 
a detailed simulation analysis of the type presented in this study for a range of Australian locations. The results emphasised the importance of stored soil moisture as a buffer against adverse rainfall patterns during the coming growing season. Results were widely disseminated amongst producers, allowing them to make their own assessments, based on specific circumstances (i.e. soil type, starting soil moisture, amount of planting rain received, desired enterprise mix etc.).

There are a range of specific management options available to producers. Hammer et al. (1996b), for instance, analysed the economic impact of adopting an tactical, SOIbased approach to nitrogen management, whereby different amounts of nitrogen fertiliser are applied based on April/May SOI phases. In addition, they investigated the impact of maturity type choice to minimise the impact of frost damage. They found that a tactical management approach when applied to either nitrogen management or variety choice can either increase profits by up to $20 \%$ and/or reduce production risks by up to $35 \%$.

Crops differ in their relative responses to climatic variability. A systems simulation capability also allows an objective evaluation of other cropping options such as crop choice. Deciding which is the most profitable crop to grow depends, among others, on the time of year, amount of stored soil moisture and commodity prices. While it might be more profitable to grow one crop when the rainfall outlook is promising, another crop might perform better when the rainfall outlook is poor. Combining the probabilistic model output with estimates of commodity prices allows a gross margin comparison of cropping options and quantifies the risks involved in the various scenarios (Jamieson et al., 1992).

A common tactical management tool is the variation in cropping intensity. If the forecast for the coming winter season is poor, a reduction in the overall area of winter crops might be appropriate in favour of summer crops in the following season.

Seasonal production forecasts can also assist producers in their marketing strategies. If it is likely that wheat yields might be suppressed as it is currently (May 1997) the case, producers will be more conservative when forward selling their crop, potentially saving them from being over hedged. Conversely, growers who hold old crop wheat stocks will likely hold onto these stocks for a higher price if Australia could be experiencing a dry spell making a large wheat crop for 1997 uncertain.

Cultivar choice based on seasonal outlook would be an obvious management strategy if cultivars were available that clearly differed in their performance under different environmental conditions. To develop such cultivars requires a tactical approach to plant breeding. To assess the value of genetic traits under varying environmental conditions, germplasm performance is usually evaluated in multi-environment trials (MET). The results from METs are then analysed to assess the relative merit of genotypes and selection strategies are applied to achieve genetic gain in the target population of environments (Cooper and Hammer, 1996). However, environmental conditions at a location can differ considerably from year to year even if certain season types (e.g. terminal water stress) are predominant in a region. Hammer et al. (1996a) showed how simulation models can be used to categorise environment types and then classify results from METs by season type rather than location. By better quantifying the environmental impact on genotypic performance, breeding cycles can be shortened considerably. Further, the models can then be used to evaluate the value of traits under a range of environmental conditions (Hammer et $a l .$, 1996b). This can lead to better adapted cultivars for specific season types. Once such cultivars are available, producers will be able to chose the most appropriate cultivar for the forecast season type. Again, the economic value for such a management option can be evaluated by simulating the production systems either with and without a strategic cultivar choice component.

\section{CONCLUSIONS}

World rainfall patterns are influenced by the ENSO phenomenon. This knowledge can be used operationally to forecast rainfall distributions and season types for many parts of the world. When combined with crop simulation models that account for the major environmental effects on crop growth, the system allows for a probabilistic forecast of likely yield outcomes at many locations. This allows producers (and others involved in agricultural production and marketing) to strategically adjust their manage- 
ment. Options range from fertiliser application, crop and cultivar choice to strategically adjusting the cropping area and determining the appropriate amount of hedging. Further applications are currentiy under development.

The above analysis was conducted in regions that are not associated with especially strong relationships with El Nifio or the SOI. Further analysis of relationships in a region such as North-eastern Brazil may identify even more substantial effects of ENSO on crop production and assist in the development of better 'tuned' seasonal climate forecast systems.

\section{REFRRENCES}

COOPER, M.; HAMMER, G.L. Synthesis of strntegies for crop improvement. In: COOPER, M. \& HAMMER, G.L. (Editors). Plant adaptation and crop improvement. CAB Imternational, ICRISAT and IRRI, p.591-623, 1996.

FISCHER, K.S. Systems approach to understanding genotype by environment interactions. In: Applications of systems approaches in plant breeding. AGGARWAL, P.K.; MATTHEWS, R.B.; KROPFF, M.J.; VAN LAAR, H.H. (Editors). SARP Research Proceedings, AB-DLO, TPE-WAU, Wageningen and IRRI, Los Bafios, 1995, p.1-4.

HAMMER, G.L;; WOODRUFF, D.R; ROBINSON, J.B. Effects of climatic variability and possible climatic change on reliability of wheat cropping - A modelling approach. Agriculture For Meteorology, v.41, p.123-142, 1987.

HAMMER, G.L.; BUTLER, D.; MUCHOW, R.C.; MENKE, H. Integrating physiological understanding and plant breeding via crop modelling and optimisation. In: COOPER, M. \& HAMMER, G.L. (Editors). Plant adap-tation and crop improvement. CAB Interna-tional, ICRISAT and IRRI, 1996a. p.419-441.

HAMMER, G.L, HOLZWORTH, D.P.; STONE, R. The value of skill in seasonal climate forecasting to wheat crop management in a region with high climatic variability. Australlen Journal of Soll Research, v.47, p.717-737, $1996 \mathrm{~b}$.

AMIESON, A; HAMMER, G.L; MENNKE, H. A computer based decision aid for sunflower, sorghum and wheat. Proceedings: 13th INTERNATIONAL SUNFLOWER CON-FERENCE, Vol. 1, 1992, Pisa, ltaly, 1992. p.202-207.

KEATING, B.A; MEINKE, H.; DIMES, J.P. Prospect for using a cropping systems simulator to assess exceptional droughts. Consultancy report, commissioned by the Bureau of Rural Resources, Canberra, Australia, 1996. 54p.
KHANDEKAR, M.L. El Niffo/Southern oscillation, Indian moswoon and world grain yields - a synthesis. Advances in Naturnl and Technolodjeal Herands Revenrch, v.7, v.79-95, 1996.

LITTLEBOY, M.; SLLBURN, D.M.; FREEBAIRN, D.M.; WOODRUFF, D.R.; HAMMER, G.L; LESLIE, J.K. Impact of soil erosion on production in cropping systems. 1. Development and validation of a simulation model. Austrilian Joumal of Sol Research, v.30, p.757-74, 1992.

LOVENSTEN, H.; LANTINGA, E.A.; RABBNNGE, R.; VAN KEULEN, H. Principles of production ecology. TPE-WAU: Wageningen, 1995. 121p.

MCCOWN, R.L; HAMMER, G.L; HARGREAVES, J.N.G.; HOLZWORTH, D.P.; FREEBAIRN, D.M. APSIM: A novel software system for model development, model testing, and simulation in agricultural research. Agricultural Systems, v.50, p.255-271, 1996.

MENKE, H.; HAMMER, G.L. A peanut simulation model. II. Assessing regional production potential. Agronomy Journal, v.87, p.1093-1099, 1995a.

MENKE, H.; HAMMER, G.L. Climatic risk to peanut production: a simulation study for northern Australia. Australion Journal of Experimental Agriculture, v.35, p.777-780, 1995b.

MEINKE, H.; CARBERRY, P.S.; KEATING, B.A.; FREEBAIRN, D.M.; TURPIN, J.; DIMES, J.D. APSIM and its use in cropping systems analysis. In: Plentinger, M.C. and Penning de Vries, F.W.T. (Editors). Rotation models for ecological farming. CAMASE/PE workshop report, DLO Research Institute for Agrobiology and Soil Fertility and C.T. de Wit Graduate School for Production Ecology, Wageningen (Quamtitative Approaches in Systems Analysis, No. 10). 1996a. p.23-33.

MEINKE, H., STONE, R.C.; HAMMER, G.L. Using SOI phases to forecast climatic risk to peanut production: a case study for northern Australinn International Journal of Cimnatolosy, v.16, p.783-789, $1996 \mathrm{~b}$.

MEINKE, H.; HAMMER, G.L. Forecasting regional crop production using SOI phases: a case study for the Australian peanut industry. Australian. Journal of Agriculture Research, v.48, 1997.(in press).

MEINKE, H.; HAMMER, G.L.; VAN KEULEN, H.; RABBNGE, $R$. Improving wheat simulation capabilities in Australia from a cropping systems perspective. III. The integrated wheat model (I_WHEAT). European Jourall of Agronomy, 1997. (in press).

NETHERLANDS SCIENTIFIC COUNCIL FOR GOVERNMENT POLICY. Ground for choices. Sdu Publishers: The Hague, 1992. 144 pp. 
STONE, R C.; HAMMER G. L.; MARCUSSEN, T. Prediction of global rainfall probabilities using phases of the Southern Oscillation Index. Nature, v.384, p.252-255, 1996a.

STONE, R; NICHOLLS, N.; HAMMER, G. Frost in NE Australia: trends and influences of phases of the Southern Oscillation. Joumal of Climate, v.9, p.1896-1909, 1996b.
WOODRUFF, D.R 'WHEATMAN' a decision support system for wheat management in subtropical Australian Jourmal Agricultural Research, v.43, p.1483-1499, 1992.

Recebido para publicaça em 15.05 .97 Aceito para publicagülo em 20.05.97 